\title{
Analyzing Consumer Disloyalty Behavior in Constantly Evolving Market
}

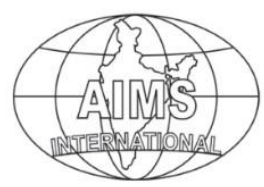

DOI: $10.26573 / 2020.14 .3 .2$

Volume 14, Number 3

September 2020, pp. 147-158

\author{
Shivam Trivedi \\ Narsee Monjee Institute of Management \\ Studies. Mumbai, India \\ (shivamtrivedi25@nmims.edu.in)
}

Consumers' willingness to switch brands has been on the rise globally. With majority of consumers actively or passively being open to trying new brands, the risk for marketers to retain customers is surging. This research paper studies the current trends of consumer disloyalty behavior and analyzes different reasons that influence the shifts in consumer loyalty. The study also includes categorizing consumers based on their brand loyalty, studying each cohort's purchase choices to gain better insights into consumer demand for choice, and how brands can focus more on marketing to minimize growing traits of disloyalty to harness loyalty.

Keywords: Consumer Loyalty, Consumer Disloyalty, Consumer Demand

\section{Introduction}

Consumer disloyalty is on the rise globally. According to a global consumer study conducted by global measurement company, Nielsen, only $8 \%$ of the consumers worldwide consider themselves to be firmly committed loyalists. Around $46 \%$ of the consumers agree that they are more likely to try new brands now than they were five years ago (McCullough, 2019). What is quite evidently visible through all these facts is that consumers' demand for choice is increasing and also the openness to try new things is quite popular in this try-it-all generation. Around $42 \%$ of consumers globally agree that they love trying new things and about 50\% of them say that though they prefer to stick with their preferred brands, they can switch brands to experiment. And around a quarter of consumers globally review products across broader ranges than ever.

This paper will discuss about the consumer disloyalty behavior trends observed worldwide and also disloyalty trends across various market segments. Globally, 39\% of the consumers mention value for money as an important factor, which influences their choice for brands followed by quality (34\%), price (32\%), convenience $(31 \%)$ and trust $(28 \%)$. This paper will further identify and analyze different levers that influence consumer choice and understand consumers based on their brand loyalty (Dick and Basu, 1994), divide them into cohorts and then further analyze each cohort's purchase choices to get a better insight into consumer loyalty behavior. On one hand, where consumers are actively on the search for new brands, brands still continue to channel their money on marketing tactics that aim at gaining and harnessing loyalty. This increases the risk for brands to stay relevant and sustainable 
in this era of constant change (Lafley and Martin, 2017). With the increase in the disposable income in developing markets and an exposure to more choices, brand dynamics is changing and is shrinking the power of big brands as consumers now are less likely to form long-lasting bonds with the brands. Though this is a positive signal for new and unknown brands, but serves as an alarm to the well-known brands.

\subsection{Global Consumer Disloyalty Trends}

In the developed markets of Europe, North America and some parts of Asia, 33\% of the consumers are open to trying new brands, viz-a-viz a larger proportion of consumers switching brands in the developing markets of Asia, Africa, Middle East and Latin America (McKenzie, 2019).

Globally, on an average, $42 \%$ of the consumers love trying new things. Figure 1 shows the global trend of consumer's predilection towards trying new brands. As can be seen, consumers in the Asia-Pacific region are most liable to switch brands as compared to European or North American consumers. Further, Figure 2 shows product category wise brand disloyalty. Figure 2 depicts that across the product categories, the global brand disloyalty is most prevalent among packaged food category.

\section{Methodology}

The vehicle used for this research was a survey, focused group discussions (FGDs) and in-depth personal interviews of consumers aged between 18-65 years from pan India region. It consisted of both qualitative and quantitative questions. A total of 400 people were surveyed through survey forms; 10 FGDs consisting of 8 people each were conducted; and 10 in-depth interviews of consumers from all sections of the society were conducted. The survey consisted of questions which focused upon brand disloyalty, their motivation levers which motivated them to switch brands, effect of their attitude, behavior towards brand loyalty and their purchase choices and behaviors. Focused Group Discussions and in-depth interviews were conducted to get deeper insights into which all factors lead a consumer to switch brands.

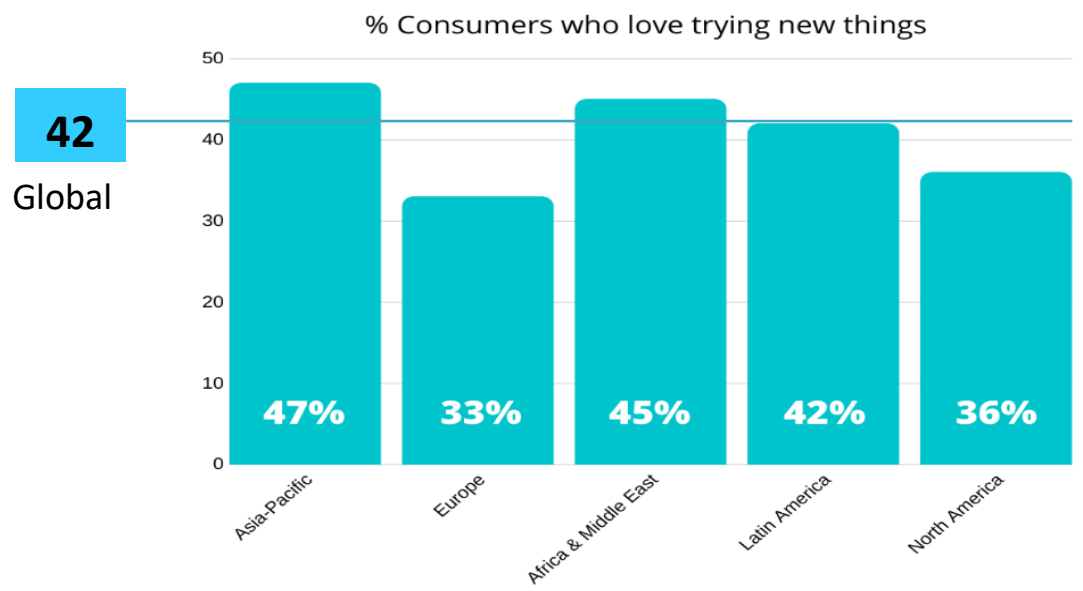

Figure 1 Global Consumer Disloyalty Trend

Source: Nielsen Global Consumer Loyalty Survey, Q1 2019 


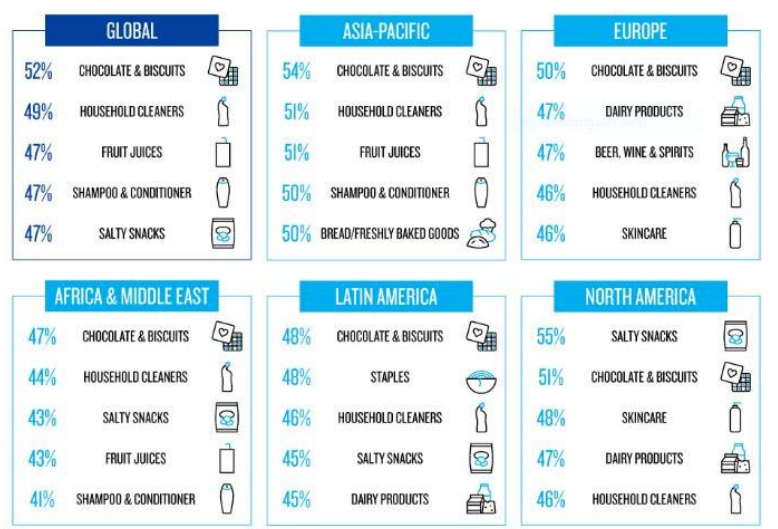

Figure 2 Product Category wise Brand Disloyalty among Global Consumers Source: Nielsen Global Consumer Loyalty Survey, Q1 2019

\section{Data Specification}

The survey forms were filled by 400 people, out of which 234 were females $(58.5 \%)$ and 166 were males (41.5\%). $21 \%$ of the survey takers were aged between 18-23 years, 32\% were aged between 23-30 years, $27 \%$ were aged between 30-40 years, $12 \%$ were aged between $40-50$ years and $8 \%$ were aged between $50-65$ years. $12 \%$ of the survey takers were from lower-middle class background, $23 \%$ were from middle class, $37 \%$ were from upper-middle class and $28 \%$ of the survey takers were from upper class background.

Table 1 Survey Takers Data

\begin{tabular}{|c|c|c|c|c|c|c|c|c|c|c|}
\hline & \multicolumn{2}{|c|}{ 18-23 years } & \multicolumn{4}{|c|}{ 23-30 years } & \multirow{2}{*}{$\begin{array}{l}30-40 \\
\text { years } \\
\text { Male }\end{array}$} & \multirow{2}{*}{$\begin{array}{c}\text { 40-50 years } \\
\text { Female }\end{array}$} & \multicolumn{2}{|c|}{ 50-60 years } \\
\hline & Male & Female & Male & Female & Male & Female & & & Male & Female \\
\hline $\begin{array}{l}\text { Lower-middle } \\
\text { class }\end{array}$ & 6 & 5 & 3 & 9 & 5 & 9 & 3 & 4 & 2 & 2 \\
\hline Middle class & 13 & 18 & 11 & 10 & 7 & 11 & 4 & 7 & 5 & 6 \\
\hline $\begin{array}{l}\text { Upper middle } \\
\text { class }\end{array}$ & 17 & 20 & 15 & 26 & 22 & 27 & 6 & 9 & 1 & 5 \\
\hline Upper class & 2 & 3 & 22 & 32 & 11 & 16 & 7 & 8 & 4 & 7 \\
\hline
\end{tabular}

Table 1 gives the information about the 400 survey takers. The FGDs consisted of 10 batches, each consisting of 8 people. 5 FGDs had people from the same age group category but different class category and another 5 FGDs had people from the same class category but different age group category. This segmentation of FGDs was done to have maximum diversity in the FGDs and to gain insights from different perspectives. Out of the 80 participants, each age category had 16 people (i.e. $20 \%$ ) and each class category had 20 people (i.e. 25\%). Table 2 shows the information of all 80 participants of the FGDs. 
Table 2 FGD Participants Data

\begin{tabular}{|l|c|c|c|c|c|c|c|c|c|c|}
\hline & \multicolumn{2}{|c|}{$\mathbf{1 8 - 2 3}$ years } & \multicolumn{2}{c|}{$\mathbf{2 3 - 3 0}$ years } & \multicolumn{2}{c|}{$\mathbf{3 0 - 4 0}$ years } & \multicolumn{2}{c|}{ 40-50 years } & \multicolumn{2}{c|}{ 50-60 years } \\
\hline & Male & Female & Male & Female & Male & Female & Male & Female & Male & Female \\
\hline Lower-middle class & 2 & 2 & 2 & 2 & 2 & 2 & 2 & 2 & 2 & 2 \\
\hline Middle class & 2 & 2 & 2 & 2 & 2 & 2 & 2 & 2 & 2 & 2 \\
\hline Upper middle class & 2 & 2 & 2 & 2 & 2 & 2 & 2 & 2 & 2 & 2 \\
\hline Upper class & 2 & 2 & 2 & 2 & 2 & 2 & 2 & 2 & 2 & 2 \\
\hline
\end{tabular}

10 in-depth interviews were taken. Out of the 10 interviewees, 6 were female and 4 were male. 2 interviewees belonged to lower-middle class, 2 to middle class, 3 to upper-middle class and 3 to upper class. Out of the 10 interviewees, 2 were students, 4 private company employees, 1 government officer, 2 house-wives and 1 businessman. 1 student and 1 private company employee belonged to lower-middle class, 1 housewife an 1 private company employee belonged to middle class, 1 student, 1 government officer and 1 private company employee belonged to upper-middle class and 1 house-wife, 1 private company employee and 1 businessman belonged to upper class category.

\section{Research Findings}

Quantitative data was derived from the survey form inputs and Qualitative data was derived from the FGDs and Interviews.

\subsection{Quantitative}

The quantitative research findings are based on the survey forms that were filled by 400 respondents. Out of $400,33 \%$ of the respondents said that they love trying new things and actively search for the latest brands and products and will easily switch to new brands if found attractive. Also, $56 \%$ people more conventionally would prefer sticking to the known brand, but can be moved to experiment. This indicates that consumers are having an upper hand when it comes to choosing brands, they are constantly looking for new and novel brands as the risk of trial nears zero.

Next, upon their choices for brands, respondents were divided into three categories: Active explorers, Active Considerers and Conscious Considerers. $40 \%$ of the survey takers choose themselves to be Active Explorers. Active Explorers are the ones who are more likely to try new or different brands than they were 5

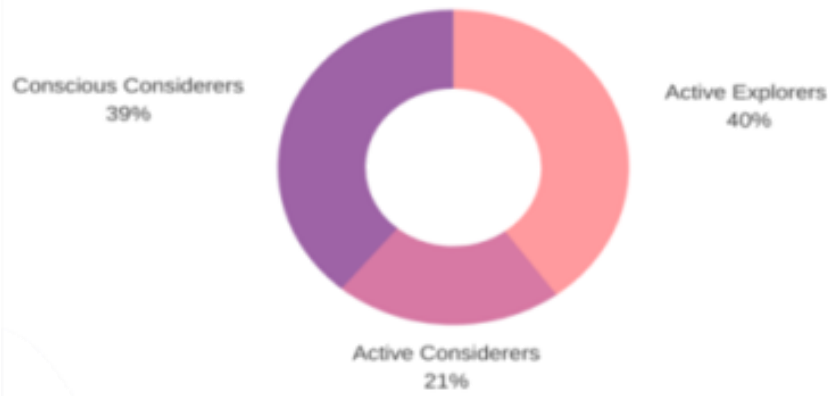

Figure 3 Categorization of Consumers based on their Purchasing Behaviour 
Years ago. 21\% of the survey takers were Active Considerers. Active Considerers are the ones who choose across more brands, across different product categories and prefer to switch brands. And $39 \%$ of the respondents filled out that they were Conscious Considerers. Conscious Considerers are the ones who choose across more brands but prefer to stay with those they have tried in the past. Figure 3 depicts the same. An inference that can be drawn from this information is that the consumers are aware and are ready to engage with larger competitive sets.

To understand the impetus which leads to consumer disloyalty, respondents were asked to rate different reasons ranging from price to convenience, in accordance with their effect on consumer's brand disloyalty behavior. Price or Value for money emerged as the biggest factor which influences disloyal behavior among customers. $32 \%$ people rated value for money the highest followed by advertisements and promotions (26\%), Superior quality (22\%) and Convenience (20\%). So Price of the product and its advertisements can be termed as Choice Drivers that tempt the consumers to try or switch brands, and Quality and Convenience can be termed as Success Drivers which are significant features of the brand/product that shape selection behavior.

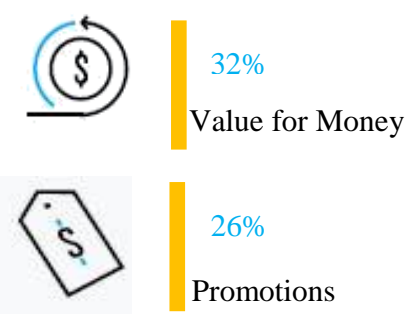

Choice Drivers

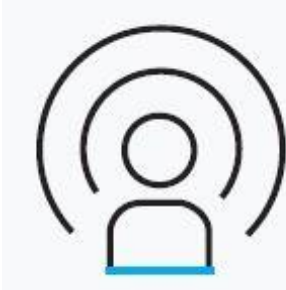

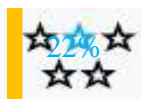

Superior Quality

Convenience
$20 \%$

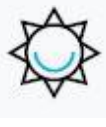

Success Drivers

Figure 4 Reasons Leading to Disloyal Behaviour

Brand familiarity is an important factor when it comes to brand loyalty. Though over the years, this factor of brand loyalty has lost its effect, it is still the most important factor chosen by consumers for brand loyalty. So the strength of well-known and trusted brands holds strong for consumers as $27 \%$ of the consumers were drawn towards offerings from those brands which they were familiar with and had established confidence in. Apart from all the tangible product features and power of the brands, consumers also focus on the values that the brands stand for. $19 \%$ of the respondents voted for loyalty for brands that are socially responsible and $16 \%$ voted for those which trade with transparency.

To understand which channel do consumers prefer more for buying products and which channel accelerates brand disloyalty, respondents were asked to mention about their buying habits, both online and offline. 57\% of the respondents said that they research and buy items online, $26 \%$ said that they research online and then buy them later in physical stores, $11 \%$ said that they prefer to research and buy items offline and only $6 \%$ prefer to research products in physical stores and then buy them online. It is quite evident that whether it is researching about the products or purchasing them, consumers these days spend a lot of time and energy on online channels. In online channels, consumers shop on various e-commerce sites such as Flipkart, Amazon, eBay, Myntra, Jabong, Big Basket, Snapdeal, Shop clues, Godrej Nature's Basket, Pepperfry.com, Urban Ladder, etc. In 
offline channels, consumers shop from mom \& pop stores, stand-alone brand showrooms, super-markets, hyper-markets, mini-markets, multi-brand outlets, branded retail, etc. In offline channels, consumer preference was higher for super-markets and multi-brand outlets as compared to mom and pop stores and stand-alone brand showrooms. The reasons identified for consumer preference for online shopping or for shopping from multi-brand outlets are ease of buying and the plethora of choices of brands and products that these channels offer. $77 \%$ of the respondents agreed that their brand disloyalty increases when they shop online and 69\% of the respondents agreed that their brand disloyalty increases when they shop via multi-brand retail channels. They identified exposure to more choices as a predominant reason leading to brand disloyalty $(89 \%)$ and also availability of greater number of products and brands at a single touch point (73\%).

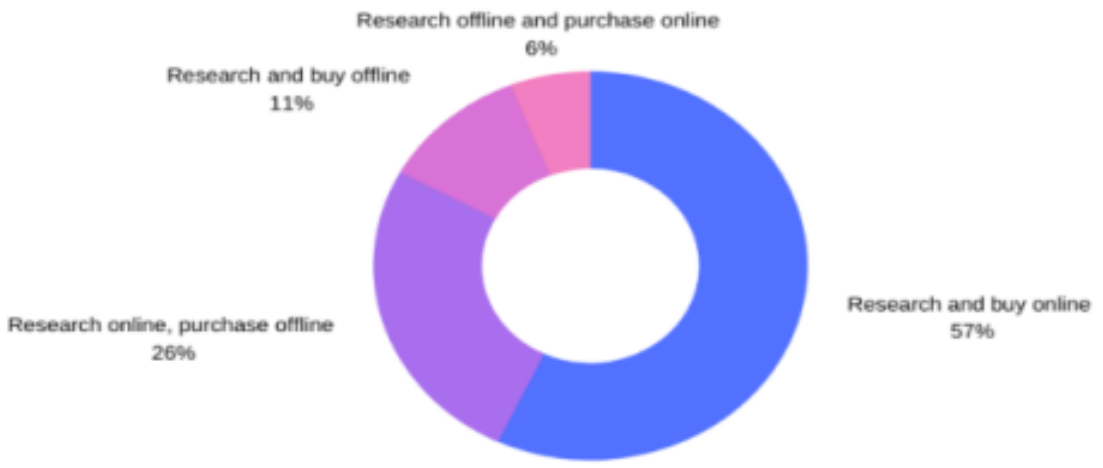

Figure 5 Channels of Purchase

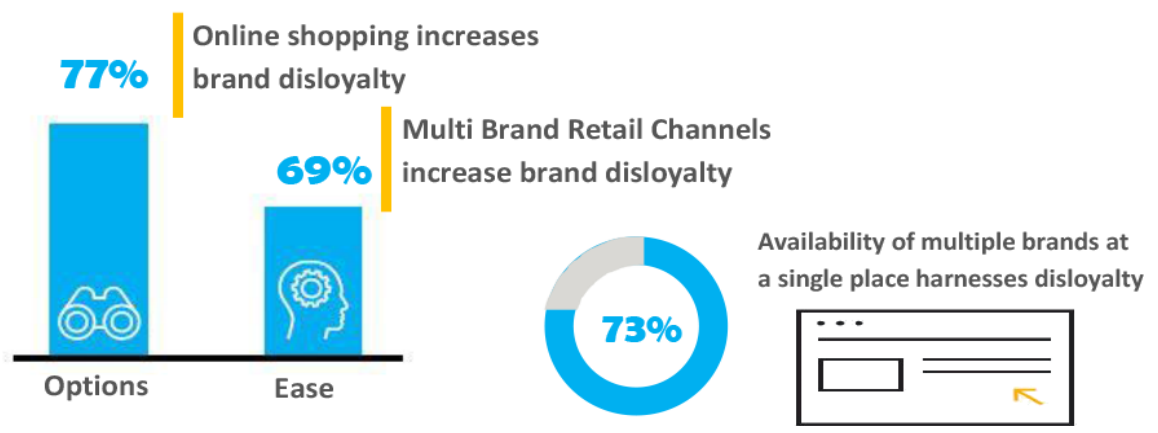

Figure 6 Brand Disloyalty Levers

When asked about switching brands in different product categories, highest brand disloyalty was observed in packaged food items (46\%) followed by household cleaners $(37 \%)$, personal-care products $(31 \%)$, stationary (29\%), skin-care products $(27 \%)$, electronic products $(19 \%)$, automobile $(12 \%)$ and cosmetics and fragrances $(8 \%)$. It can be inferred from the above observation that for high involvement products, consumers' tendency to switch brands is low when compared with that for low involvement products. 
Exposure to more Brand and Product

\section{Choices Harnesses Disloyalty}

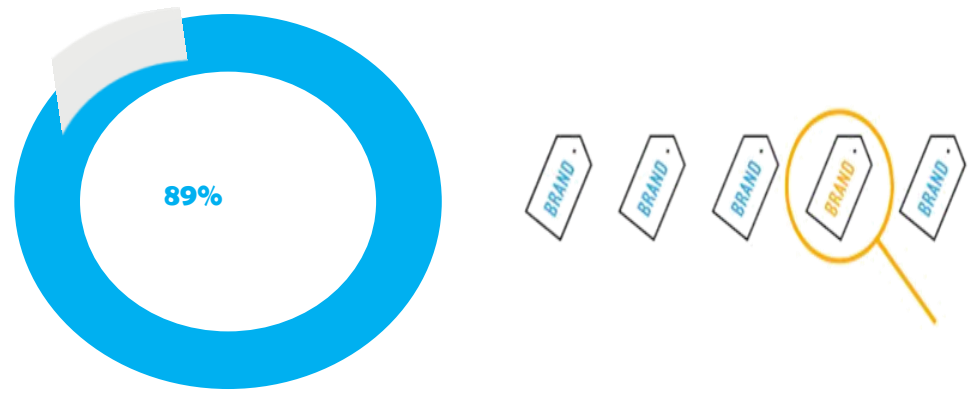

Figure 7 Brand Disloyalty Levers

\subsection{Qualitative}

The qualitative research findings are based on the 10 Focus Group Discussions and 10 in-depth interviews. From the responses of the FGD participants and interviewees, it was established that consumers are now actively on the lookout for new brands which has led to an increase in the number of trials and experimentation of new products and brands. The major reason behind the same was the rising disposable income in developing markets like India. With choices at an all-time high, switching brands has now become a very unconscious decision as compared to five years ago.

In order to understand the correlation between the degree of brand loyalty and risk taking attitude of consumers (East, Sinclair and Gendall, 2000), we mapped a 2dimensional correlation grid that maps the degree to risk taking attitude against the degree to brand loyalty. Cross-classification of two levels of each of these has led us to consider four conditions.

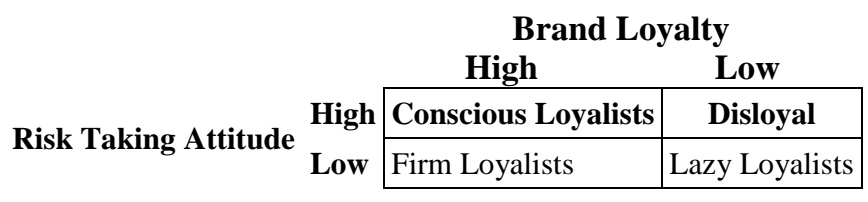

Conscious loyalists (37\%) are those whose risk taking appetite is high and brand loyalty is also high. So such consumers will switch brand only after consciously comparing alternatives and choosing the one which suits their criteria. Disloyal consumers (24\%) are the ones whose risk taking appetite is high and brand loyalty is low. Such consumers can be easily made to switch brands. Levers such as price change, advertisements, promotions and discounts will tempt such consumers to make a shift. Firm loyalists $(11 \%)$ are a minority and they prefer not to take risks and seldom buy from new brands. And the last category is Lazy Loyalists (28\%), as they are stuck in the past buying the same brands as before and staying with their favorite ones, but when provided with a better deal they may also switch brands. 
From the responses of the interviewees, an underlying insight was derived that there is no doubt that price sensitivity is a major factor leading to disloyalty, but price sensitivity is less important than value. Consumer these days have become more careful about the products and brands that they are associated with and are ready to turn away from the brands that do not resonate with their life-style and values (Bennett and Boye, 2001). As the choices and alternatives have increased, the phenomenon of making a choice has also become difficult. As the act of choosing becomes difficult, consumers either go back to their preferred brand or established brand or they seek help in deciding which brand's product best matches their own personal shopping criteria. A positive word of mouth for any brand can pull attention/ create attraction. Here, affiliate marketing comes into picture which influences the buying decisions of consumers. But trust is the key here. As participants suggested during their interviews, affiliates influence the buying decisions to a greater extent, given that they impart authentic advice and are also transparent about their advertising activity. But if this trust is damaged by not disclosing what is genuine and what a sponsored ad is, consumer's loyalty towards the brand gets damaged.

Customers value opinion but advertising is still the predominant vehicle which increases the reach of a brand and prompts a call to action. When asked about the effect of manipulation by media and advertisements on disloyalty, $16 \%$ people responded that brands with earned presence via recommendations, PR articles and reviews prompt disloyal actions. Only $7 \%$ of them said that marketing and advertisement efforts are less persuasive and don't help in building loyalty towards brands.

To gain better insights on consumer disloyalty, using the responses of the FGD and Interview participants, we tried constructing a relationship between consumer's attitude, behavior towards the brand, social norms, situational influence and brand disloyalty (Ramachandran, 2015). Through this activity, different reasons for brand disloyalty were identified which serve as the focus areas on which marketers can focus upon to harness consumer loyalty.

Absurd Disloyalty: Low repeat purchases can be there because of more brands stocked by retailers, different usage situations, variety seeking attitude, and bad mood or negative emotions. This kind of disloyalty pattern is very random but these were quite prominently brought forth by the group discussion participants.

Lack of Funds: Many times lack of funds to purchase regular brand or an alternative brand also leads to shift in purchases.

Individual's Perception of the Brand: When a brand is associated with a strong attitude and is clearly differentiated among its competitors in the consumer's mind, loyalty towards that brand is established. Also a weak attitude but clear differentiation will lead to loyalty (Rust and Zahoric, 1993). On the other hand, a strong attitude with weak differentiation will lead to multi-brand loyalty as alternatives are viewed as almost equals. A weak attitude coupled with weak differentiation will lead to decrease in repeat purchases and will also vary based on situations and non-attitudinal influences. 
Advertisement: Information of brands obtained through advertisements, and acceptance of information is low as the source is perceived to have a vested interest. Advertisements lead to tentative beliefs towards the brand and may hamper brand loyalty.

Direct Experience: It increases brand information acceptance and trust, leads to beliefs which are based on trials, and results in purchase commitment, increasing repeat purchases (if the experience was worth a repeat purchase).

Satisfaction: When consumer expectations and perceived performance of a product don't match, the resulting dissatisfaction leads to disloyalty and reflects in the postpurchase response of the consumer.

Switching Costs: It is the one-time cost that one bears to switch from one brand to another. Low switching cost encourages curiosity and increases tendency for trial and hence, encourages/creates/motivates disloyalty. Apart from the objective monetary costs, switching cost can also have psychological interpretations, like frustration of attempting to understand the shelf allocation of a new store.

Subscriptions: When consumers are bound by some sort of subscription, their repeat purchase or interaction with the brand increases.

Social Norms: Social and societal norms also impact brand disloyalty. If a particular product or brand is a misfit to a person's surroundings or personality, naturally, the customer will switch to another offering or company. Social influences such as relative attitude of family, friends, and colleagues also impact patronage decision of a consumer. So as the heterogeneity in relative attitude among the surrounding set of influential individuals increases, the likelihood of exhibit of loyalty decreases.

Situational Influence: Situational influences that hamper brand loyalty are: case of stock out of preferred brand; deals, offers and discounts on certain products or competing brands; disruptive advertisement and marketing campaigns by competitive brands that evoke curiosity among customers; and effective in-store promotions.

Information about Alternatives: Negative experience with a brand increases the search for alternatives. Consumer engaging in more processing of brand/productrelated information facilitates disloyalty.

Volatility of Market: Volatile markets where there are frequent entries of new offerings, different brands delivering different benefits, and customer sensitivity to new information, loyalty formation becomes difficult.

\section{Results and Discussion}

Results of the primary research and secondary research indicate towards the fact that disloyalty is at an all-time high and poses challenges to today's marketers to manage their brands well so as to harness brand loyalty out of their marketing strategies. In 
Results and Discussions, we will discuss some of the points which marketers can keep in mind while dealing with the shifting consumer interests.

First of all, they need to work on delivering an effortless experience to the customers. Creating effortless experience for customers automatically drives them towards the brand again to repurchase and increase spending. This can be done by measuring efforts of consumers, which can be reduced by identifying issues and prioritizing customer service investments and providing multichannel and Omni channel service (Jacoby and Chestnut, 1978).

It needs to be kept in mind that now-a-days the target group is not a mass, i.e., illdefined set of loyal customers, but the interest of the individual. Brand managers can use analytics to engage and understand intimately their customers and launch content that is specific to each consumer. To create a strong proposition which resonates with customers at an individual level, the brand needs to exist in the customer's life by fulfilling a personal need to serve a purpose (Day, Gan, Gendall and Esslemont, 1991). The marketers need to identify the disloyalty levers that entice potential customers to switch to something new so as to discover the touch-points of customer disloyalty. Dive into customers' hearts. Disloyalty comes from the power to make choice. Consumers want to be take risks and want choices to try something new. Today's try-it-all consumers don't stick to perfect brands but rather the one which stands apart.

From now on, focus of the companies will be to embrace consumer disloyalty, understand the levers and analyze the touch points. The brands need to try and understand consumers' constantly changing needs and demands in order to stay ahead of them. The new objective, now, should be to establish a more fluid relationship with consumers with the understanding that consumers will bend towards disloyalty given the volume of choices they are subjected to (Uncles, Dowling and Hammond, 2003). Marketers need to keep it personal, keep it real, keep it fun and interesting and leverage data and analytics to provide the customers with what they want.

Apart from that, relevancy and superiority of the brand also retains and attracts customers. It is important to understand that in a world of infinite innovation and communication, just propagating company's value proposition to the conscious consumers to make your brand as their $1^{\text {st }}$ choice won't bring sustainability. Psychologists say that while choosing a brand, customer's subconscious mind plays a major role in decision making. Products and services that are more visible, easy to access and that make buying process comfortable will slowly take over even those brands which have good value proposition but which are hard to find.

Marketers and advertisers have adapted to this alternative worldview, where the best outcome is when choosing your offering becomes an automatic consumer response by highlighting multiple benefits of a new product or service (Robert, Patricia et. al., 1998). But the reality is that our minds are lazy and don't want to take in dozens of information with high level of complexity. Rather it wants to comprehend easy to digest messages so that customers can incorporate your offering into their daily life. So basically it all begins with making your brand a habit. Eventually habits turn into values, thus making your brand more sustainable. By making a brand a value — a part of someone's identity — marketers can gain a really powerful competitive edge. 
Task of managing loyalty would also involve benchmarking loyalty status with the rivals; identifying relevant potent brands and their effect on your business and determining the contributions leading to disloyalty and the probability of varied consequences so that loyalty can be achieved through strategic interventions (Rowley and Dawes, 2000). Basis the loyalty status of an entity and the relative sensitivities of a pre-dominant brand and mediating variables, the managerial challenge is to maintain the loyalty status through specific marketing inputs.

In case of convenience goods which are of low involvement and are purchased frequently, repeat purchase can be enhanced by repeated advertising using distinctive branding assets such as logo or package (Dick and Basu, 1994). Also purchase can be increased by reminding consumers of their past occasion purchases and such messages can be communicated to the consumers through a text message or through a direct mail. For specialty or shopping goods which involve a little more deliberate process, similar confidence building exercise can be done like reminding the consumer of their previous purchase with your brand or using appropriate reviews or testimonials to build more trust (Jacoby and Kyner, 1973). Talking about selfexpressive products such as fashion or perfume or cosmetics, advertising and in-store promotion through emotional identification with symbols such as country of origin of the product, spokes models and arousal devices in the environmental design of the store that create a nostalgia in the consumers' mind for future purchases, thus helping the brand to set it apart from its competitors. For no or very low-loyalty products, aggressive trade or sales promotions in the form of offers, freebies, discounts or coupons may work in attracting customers (Prichard, Hayitz and Howard, 1999). For goods where purchase is influenced by social norms, selecting appropriate retailers and salespersons who display appropriate lifestyle characteristics similar to that of the consumer segment, becomes important in affirming brand choice.

\section{Conclusion}

In this research paper, we discussed about the rising disloyalty levels among consumers in today's evolving market scenario. Using secondary research and primary research, both qualitative and quantitative, we understood the different levers causing the consumers to switch brands and effectiveness of advertisements in retaining customers. Then, based on the responses of the primary research, we divided the customers based on their loyalty and understood the reasons behind the extent of their affinity towards any brand. Upon analysis, price sensitivity and proliferation of choices came out as clear reasons for increasing disloyalty among consumers. But apart from these two, it was observed that the value, for which a particular brand stands for, also plays a very important role in influencing consumer's choice of brand. Lastly, we suggested some of the key aspects which the marketers and advertisers can leverage to harness consumer loyalty for their brands.

\section{References}

1. Bennett, R. and Bove, L., 2001, 'Identifying the key issues for measuring loyalty', Australasian Journal of Market Research 9 (2), 27-44. 
2. Day, D., Gan, B., Gendall, P. and Esslemont, D., 1991, 'Predicting purchase behaviour', Marketing Bulletin 2, 18- 30.

3. Dick, A. and Basu, K., 1994, 'Customer loyalty: towards an integrated framework', Journal of the Academy of Marketing Science 22 (2), 99-113.

4. East, R., Sinclair, J. and Gendall, P., 2000, 'Loyalty: testing the Dick and Basu model', Proceedings of ANZMAC Conference, Griffith University, Gold Coast, November, CD-ROM.

5. Lafley, A.G. and Martin, R.L., 2017, 'Customer Loyalty is Overrated', Retrieved from https://hbr.org/2017/01/customer-loyalty-is-overrated.

6. Jacoby, J. and Chestnut, R., 1978, 'Brand loyalty measurement and management', Wiley, New York.

7. Jacoby, J. and Kyner, D., 1973, 'Brand loyalty v. repeat purchase behaviour', Journal of Marketing Research 10, 19.

8. McCullough, L., 2019, 'Will your customer relationships survive infidelity?', retrieved from https://www.nielsen.com/ie/en/insights/article/2019/will-yourcustomer-relationships-survive-infidelity/.

9. McKenzie, s., 2019, 'Consumer Disloyalty is the new normal', Retrieved from https://www.nielsen.com/ie/en/insights/article/2019/consumer-disloyalty-is-thenew-normal/.

10. Prichard, M., Havitz M. and Howard, D., 1999, 'Analysing the commitmentloyalty link in service contexts', Journal of the Academy of Marketing Science 27 (3), 333-348.

11. Ramachandran, Sunder, 2015, 'Understanding brand loyalty and disloyalty formation among consumers' of short life-cycle products', University of OULU Graduate School, University of OULU, OULU Business School, Department of Marketing.

12. Robert E., Patricia H., Wendy L. and Gill W., Kathy H., 1998, 'Customer Defection from Supermarkets' in NA - Advances in Consumer Research Volume 25, eds. Joseph W.Alba\&J. Wesley Hutchinson, Provo, UT: Association for Consumer Research, pages: 507-512.

13. Rowley, J. and Dawes, J., 2000, 'Disloyalty: a closer look at non-loyals', Journal of Consumer Marketing, Vol. 17 No. 6, pp. 538-547.

14. Rust, R.T and Zahoric, A.J., 1993, 'Customer Satisfaction, customer retention and market share', Journal of Retailing, 69,2,193-215.

15. Uncles, M.D., Dowling, G.R. and Hammond, K., 2003, 'Customer loyalty and customer loyalty programs', Journal of Consumer Marketing 20 (4), 294-316.

\section{About Our Author}

Shivam Trivedi is currently pursuing his MBA from Narsee Moonjee Institute of Management Studies, Mumbai, India. He staunchly believes that success follows when we focus on delivering value and growing with every opportunity through experiential learning and collaborative effort. Being an ardent believer of the saying that age is just a number, at the age of 23 , Trivedi has previously presented his work at 5 different international platforms and has 2 international publications to his credit. His work is primarily focused on studying the consumer landscape for identifying consumer purchasing patterns and consumer behaviour. 